\title{
A People's History of the French Revolution
}

Review Number: 1736

Publish date: Thursday, 26 February, 2015

Author: Eric Hazan

ISBN: 9781781685891

Date of Publication: 2014

Price: $£ 19.99$

Pages: 368pp.

Publisher: Verso

Publisher url: http://www.versobooks.com/books/1707-a-people-s-history-of-the-french-revolution Place of Publication: London

Reviewer: Michiel Rys

A People's History of the French Revolution is David Fernbach's translation of Eric Hazan's 2012 book Une histoire de la Révolution française. The change of title hints at what indeed is Hazan's original stance in his account of this historical event, an event that up to now has never ceased to fascinate writers and intellectuals. Moreover, it is not a coincidence that Hazan's History of the French Revolution appeared under this title in Verso Books, a publishing house famous for its stimulating critical books. Among these books are not only several people's histories (of Scotland, London etc.) but also a couple of reassessments of the French Revolution, such as the thought-provoking essay by Sophie Wahnich.(1) In Wahnich's analysis, 'Terror' has to be taken as an ultimate violent reflex, a last resort. It occurs at exactly those crucial and highly emotive moments, when the popular cause is under pressure and is betrayed by the representatives of the people. Hazan too tries to capture the anxieties of the people, tries to understand the course of events and is not tempted to take any a priori negative stance towards revolutionary violence.

This position comes to the fore exemplarily in his short history of the semiotics of terror (pp. 299-303). Hazan makes a compelling case that (Jacobin) Terror is an ideological construct that is used as a rhetorical instrument to attack the political enemies of the Thermodorians (an idea also put forth by others, such as Alain Badiou (2)). Hazan suggests that Terror was another term for justice. Such a reading is in line with Sophie Wahnich's analyses, which try to break the alleged genealogical link between revolutionary Terror and totalitarian state violence in the last century. Moreover, Hazan's interpretation is a subtler version of Slavoj Žižek's radical, mobilizing reappraisal of Maximilien Robespierre's 'Divine Terror'. In a foreword to a selection of Robespierre's speeches, Žižek pleads for radically alternative politics in a more just society and thinks beyond capitalism and its social, economic and ecological catastrophes.(3) 
Hazan tries to kindle revolutionary enthusiasm as well and sees the world-changing potential of the French Revolution in contrast with our own neoliberal epoch, which is paralysed by a deep sentiment of political resignation and relativism. This can be illustrated by quotes such as 'In our own day, when 'politics' no longer arouses so much passion, it is hard to imagine what went on in people's minds when each day brought fresh rumours and surprises' (p. 122). An absolute strength of this comparative confrontation is that Hazan does try to differentiate between politics in the French Revolution and contemporary politics. The idea that there were no political parties in the contemporary sense is one of the mantras of the book.

From the above, it might already have become clear that Hazan does not try to deliver an objective historiographic account on the French Revolution. He makes no claims of totality whatsoever and labels his history rather modestly as 'a narrative':
'What I have tried to do, at all events, is present a narrative of the French Revolution: the fourteen chapters follow one another chronologically without digressions [...]. The narrative form is a montage that tightly links the two great revolutionary stages, that of the elected assemblies and that of the people - high eloquence and the rumbling that acts as it basso continuo, and becomes so powerful at times that nothing else is heard' (pp. 7-8).

Hazan succeeds in staging the people time and again as powerful actor in the course of revolutionary events. Over and over, the gap between the material needs of the people and the political and revolutionary realm is presented as the driving force behind pre-revolutionary rebellions and revolutionary action. The leitmotiv that 'the shortage and high price of bread [...] fuelled the rebellions' (p. 72) cannot be misheard. Hazan begins his narration with the question whether the material factors of unemployment, poverty and hunger or the self-destruction of the already moribund Ancien Régime lie at the basis of revolution. This is already a controversial topic on which historians disagree. Hazan clearly tries to find a nuanced explanation for the diverse proposed interpretations of Furet, Tocqueville, Taine, Mathiez, Jaurès: (1) they relate to different periods of time. Economic growth does fall back between 1787-9 because of the liberation of the market, and as a result of a catastrophic harvest and the high food prices; (2) a small minority benefits from economic growth; (3) competition with industrialized Britain leads to unemployment in (e.g.) silk industry.

One of the biggest strengths of Hazan's argument is the way in which he confronts different points of view before venturing a fact-oriented, personal explanation. Thus, after he elaborated on the facts, Hazan shows how Mathiez's thesis that the French Revolution was an unavoidable result of material factors is the most plausible one. A quiet, peaceful revolution as the one in America - the ideal of the liberal tradition - was according to Mathiez and Hazan no option for the people of France.

One of Hazan's digressions contests a dominant Marxist reading of the French Revolution as a bourgeois revolution (pp. 82-3) This is a peculiar statement given the main thread and focus of his narrative. The author cites three reasons to undermine the Marxist thesis. The first one is that feudalism had already come to an end. The other two render his argument more vulnerable. Firstly, the people here are opposed to the establishment of capitalism, and this does not fit in the strict Marxist scheme of history. In a traditional Marxist view, the people collaborated with what later would become the bourgeois class. They would fight this new class society only in a later stage. Lastly ' $[t]$ he bourgeoisie did not exist as a class' since the word was only used sparsely. 'There were certainly rich and poor, haves and have-nots, but this does not amount to a bourgeoisie and proletariat' (p. 83). But isn't the Marxist argument also that exactly this distinction between those who do and don't possess paved the way to capitalist society? This is the way Herbert Marcuse interprets Marx in his essay Study on Authority, and Max Horkheimer reads the revolution in his article on egoism and liberty movements.(4) The material reality of 'haves and have-nots' makes the latter economically and politically dependent of the former, resulting in an authoritative alienation relationship that is typical of capitalism. 
This remark should be considered a mere side-note. In fact, the rest of Hazan's book shows how the discrepancy between the demands of the people and the acts of the political representatives works as a driving force behind (popular) revolutionary action. Hazan at times (explicitly) hints at the class struggle between third and fourth estate, immediately tackling the very idea of a homogenous third estate famously described by Sieyès. This class reality is depicted very well later on, when Hazan describes how 'the possessor class' tried 'to limit the executive powers of the monarchy, and to keep the people well away from major decisions and the distribution of wealth' (p. 104). On page 175, Hazan defines the 'sans-culottes' in terms of property. The same goes for the women who marched to Versailles. They screamed for bread, they were 'poor and anonymous' (p. 87) Also, Sieyès' distinction between active and passive citizens (or 'the true stakeholders of the great social undertaking' and the 'labouring machines' without property) is in line with the Marxist interpretation. The concept of class is often named explicitly:

'The dead of the Champ-de-Mars were not the only victims of that day. What also died was such understanding as still remained between the possessor classes and the poor, between those who had come to power on the shoulders of the people and those who had no hesitation in shooting them down' (p. 133).

Exactly at these instances, Robespierre (who supports universal suffrage and contests the property based distinction between active and passive citizens and who was an advocate of popular vengeance after the Tuileries massacre) and Grégoire are praised as defenders of the electoral rights of the poor non-possessing people against state authority. In the National Assembly, Robespierre and Mirabeau raised their voices against the principle of martial law, which was proposed in order to contain gatherings that were considered to be dangerous. They understood the people's need for bread and stood up as spokesmen of popular movements that strived for socio-economic change.

'The demands of the sans-culottes focused on three distinct issues: the price of provisions, equality of consumption, and democracy in the sections' (p. 176) These three popular requirements are indeed the main thematic connecting threads throughout Hazan's history of the French Revolution. It is the economic and social failure of Roland's Girondin government that resulted in a severe provision crisis and high bread prices. This is criticized by Saint-Just, Robespierre and Jacques Roux, whom Hazan depicts as true representatives for the people and critics of capitalist logic, property and commodity exchange in a free market situation.

Later on in the revolution, Saint-Just proposed to confiscate the property of aristocrats (or rather enemies of the state) to give it to the poor. The measure was misunderstood by the beneficiaries, but Hazan again evaluates Saint-Just's law through the eyes of the general will (pp. 349-351). Roland's liberal politics resulted in 'hatred of the Gironde now spread among the people of both town and country' (p. 212). This anti-Girondin sentiment increases and spreads: 'The month of February 1793 was marked by a strong movement against free-market economics, and for the fixing of a maximum price on commodities' (pp. 230-1). Moreover, the fall of the Gironde is represented as a 'parliamentary revolution'. Again, this power struggle in the French Revolution does not find its source in the people itself. It is in this respect that Hazan criticizes this event:

'The people had attacked the Bastille and the Tuileries in a spontaneous impulse, whereas this time the popular movement was encased in a parliamentary revolution with some of the features of a coup d'état. And indeed the fall of the Girondins was not greeted by great displays of popular joy, as the previous revolutions had been' (p. 246).

After the fall of the Gironde, efforts were made towards a new constitution, which proposes a complicated but democratic elective system. With Robespierre's draft of a new declaration of rights, the old question of property arises once again. Robespierre opposes to Condercet's liberal conception of property as a never- 
seen, revolutionary subordination of the right to property to the general good. The fact that his suggestion about property isn't implemented by the Convention sustains the (Marxist) thesis that this is a bourgeois revolution that aims at the protection of the material basis of early capitalist society: private property. Jacques Roux, whom Hazan stylizes as spokesperson for the demands of the popular movement, did not find the declaration and constitution radical enough, and reacts in the Enragés Manifesto. Again, Hazan illustrates here how popular pressure has greatly influenced the policy of the Committee of Public Safety. At stake is the famous maximum price for basic and necessary commodities. 'Thus the same Assembly that had booed Jacques Roux two days earlier was gradually advancing towards the realization of his programme' (p. 277).

Hazan evaluates all protagonists of the Revolution by examining their relationship with the popular movements. This is not only the case for Robespierre but also for the Convention (such as Vergniaud) and the Girondins:

'[T]he Convention certainly was the first and only French national assembly in which the people were able to make their voice directly heard [from the galleries or through letters]' (p. 197).

'The Girondins were afraid, in fact, that the king's deposition would unleash an uncontrollable popular movement' (p. 167).

Yet the deposition is exactly the demand of the sections and the people. Vergniaud, first supporting the monarchy, is obliged to change his opinion: 'When the triumph of the insurrection began to seem increasingly inevitable, this commitment was watered down until it turned into its opposite' (p. 173).

Hazan describes Jean Paul Marat through the eyes of the people, but the explicit sketch of his prophetic powers has a rather strange effect and even seems to give him a hagiographic aura. Hazan tries to express objectified views on Danton as well, choosing for the middle way between Alphonse Aulard's glorification and Albert Mathiez's repudiation. I particularly appreciate Hazan's description of the Jacobin club, Robespierre and the Jacobin legacy throughout history. Hazan nuances radical adversaries of the Jacobins and in this way shatters a myth:

'The society and its branches operated as a system for spreading revolutionary ideas across the country. Nothing is more absurd than the idea of 'Jacobinism' as an authoritarian and meddlesome Paris dictatorship. That is an interpretation handed down by Thermidor, as lasting as hatred of the Revolution' (p. 94).

The author wants to get rid of the flat image that Robespierre was a bloodthirsty tyrant. He makes a compelling case, which is in line with other views on Robespierre that were developed in the last two decennia.(5) In fact, Robespierre is shown as a figure of the middle: decisions were made by the Committee of Public Safety as a collective. Robespierre even did many things to save individual lives. The main argument that speaks against Robespierre is that he halted the popular movements at work. Again, the revolutionary leader and his political actions are measured against the unavoidable background of the people. Eventually, his rupture with the Commune concerning the implementation of a maximum wage led to his eventual downfall.

Hazan unambiguously chooses sides of popular movements, and uses presuppositions such as ' $[\mathrm{t}] \mathrm{he}$ repression had begun'; or bold statements, which are often found in the personal interpretations of the many excursus. Discussing the storming of the Bastille, Hazan does not hide his own opinion on this event:

'[T]he storming of the Bastille was one shining point on the trajectory of the Paris insurrection, which continued its upward curve on 10 August 1792 and 31 May - 2 June 1793, before falling tragically back again after Thermidor, with the hunger riots of Prairial in year III' (p. 71, my 
emphasis).

The author makes a valuable case that the de-Christianization movement was the result of the interaction of people and revolutionary leaders. The fact that the latter invented a whole range of festivals, rites, habits - in short cultural politics - to educate the people civically and morally, is by now a common place in studies on the French Revolution. However, it is quite revolutionary that Hazan takes the idea of republican virtue as a politics that is sustained and demanded by the people, instead of only being installed by the force of revolutionary government (p. 316) Concerning the right to education, the people even reprehended ' $[\mathrm{t}] \mathrm{he}$ slowness of the law's application [that] led to popular recriminations' (p. 317). The same goes for his discussion of Terror. The later demonized revolutionary tribunal and guillotine are depicted as instruments which were at the time approved by the discontent people. 'The word on the street was that only the guillotine could sort matters out' (p. 347).

Hazan has succeeded in delivering a vivid, lucid, informative, detailed account of the French Revolution. The author confronts different (revolutionary and counterrevolutionary) angles and interpretations of revolutionary events; he even demystifies some concepts and legends developed after Thermidor. Hazan uses original sources and confronts them with the classic historiographies, but also with some more recent investigations into aspects of the French Revolution. One certainly should not exaggerate Serge Bianchi's critique that Hazan's sources 'semblent s'arrêter aux années 1970'. (6) Of course, his chronological overview does not encompass all aspects of the revolution in every detail - but this was not the goal Hazan set out for himself. A People's History of the French Revolution surely is a fascinating encounter with what is to be considered one of the founding events of modern Western society. It illustrates how the power resides in the people - something Hazan clearly wants us to remember.

\section{Notes}

1. Sophie Wahnich, In Defence of the Terror (London, 2012).Back to (1)

2. Alain Badiou, Metapolitics (London, 2005).Back to (2)

3. Maximilien Robespierre, Slavoj Zizek presents Robespierre. Virtue and Terror (London, 2007). Back to (3)

4. Herbert Marcuse, 'Studie über Autorität und Familie', in Schriften. Band 3. Aufsätze aus der Zeitschrift für Sozialforschung 1934-1941 (Frankfurt am Main, 1979), pp. 85-184; Max Horkheimer, 'Egoismus und Freiheitsbewegung. Zur Anthropologie des bürgerlichen Zeitalters', Zeitschrift für Sozialforschung, 5, 2 (1936), 161-234.Back to (4)

5. Michel Biard \& Philippe Bourdin, Robespierre. Portraits croisés (Paris, 2012); William Doyle \& Colin Haydon, Robespierre (Cambridge, 1999).Back to (5)

6. Serge Bianchi and Éric Hazan, 'Une histoire de la Révolution française', Annales historiques de la Révolution française, 371 (2013), 204-6.Back to (6)

\section{Other reviews:}

Guardian

http://www.theguardian.com/books/2014/sep/17/peoples-history-french-revolution-eric-hazan-review [2]

Spectator

http://www.spectator.co.uk/books/9297212/a-peoples-history-of-the-french-revolution-by-eric-hazan-review/

[3]

Morning Star

http://www.spectator.co.uk/books/9297212/a-peoples-history-of-the-french-revolution-by-eric-hazan-review/ [3]

Source URL:https://reviews.history.ac.uk/review/1736

\section{Links}

[1] https://reviews.history.ac.uk/item/122532 [2] http://www.theguardian.com/books/2014/sep/17/peopleshistory-french-revolution-eric-hazan-review 
[3] http://www.spectator.co.uk/books/9297212/a-peoples-history-of-the-french-revolution-by-eric-hazanreview/ 